\title{
The Australian delegation to the 1919 Paris Peace Conference: A biography
}

\section{DAVID LEE}

The Australian delegation to the Paris Peace Conference of 1919 had 3 significant achievements. The delegation secured a position for the 'Dominion' of Australia, often still described as 'colony', in a major international peace conference. It won a place for Australia in the new international organisation, the League of Nations, established by the Peace Conference, and it obtained responsibility from the League for mandates over the former German territories of New Guinea and Nauru. The separate signing of the Peace Treaty by Australian plenipotentiaries was a significant step in Australia's transition from colony to independent nation-state that could not be effaced. Key members of the delegation were W.M. Hughes, the wartime prime minister affectionately known as the 'little digger', Joseph Cook, a former prime minister and minister for the navy, and 3 members of the Round Table Movement that encouraged closer union between Britain and its dominions: LieutenantCommander John Greig Latham, Cook's adviser; Sir Robert Garran, permanent secretary of the Commonwealth Attorney-General's Department, solicitor-general since 1916 and Australia's most distinguished public servant; and Frederic Eggleston, a Victorian lawyer and army officer.

Previous studies of Hughes's overseas diplomacy in 1918 and 1919 have tended to attribute all of the outcomes to the prime minister's energy and leadership. As for the wider delegation, they have referred to Cook's minimal influence, Garran's personal loyalty to Hughes, Latham's legal skills, and Eggleston as a disgruntled observer. W.J. Hudson concluded that 'there is nothing to suggest that on any important issue Hughes was inhibited by his advisers'. ${ }^{1}$ Malcolm Booker went further to argue that Hughes was 'for the most part badly served' by his advisers with both Latham and Eggleston very much under the influence of the British diplomats and public servants. ${ }^{2}$ While agreeing that Hughes exercised the dominant influence in London and Paris in 1918 and 1919, the argument of this article is that the delegation was important in supporting Hughes in diplomacy that was contrary to the wishes of his cabinet colleagues back in Australia, and the British Government. The Australian

W. J. Hudson, Billy Hughes in Paris: The Birth of Australian Diplomacy (Melbourne: Thomas Nelson, 1978), 63. Malcolm Booker, The Great Professional: A Study of W. M. Hughes (Sydney: McGraw-Hill, 1980), 239-40. 
delegation was motivated to help Hughes become the most assertive advocate for dominion interests in Paris because it felt that Australia had more at stake in the peace negotiations than other dominion: Australia's very security. This strategic concern emboldened the delegation to support Hughes in claiming for Australia a role at a major international conference that many Australians thought was inappropriate for a dominion. In doing so, they laid the foundation for Australian independence. This article does not consider Hughes's campaign for reparations because in this he was following a wider Empire line, one eventually softened by British Prime Minister David Lloyd George and South African Prime Minister Jan Smuts for diplomatic reasons.

\section{Dominion representation at the Peace Conference}

Hughes was born in London in 1862, son of a carpenter and Welsh-speaking deacon of the Baptist Church from North Wales. He migrated to the Australian colonies in the 1880s, gravitated to unionism and the newly formed Labor Party and won election to the seat of West Sydney in the federal parliament in 1901. Hughes held office in Labor administrations during the first decade after Federation. An advocate of centralised Commonwealth powers, Hughes was also a staunch supporter of Empire, even trying to dispense with the double dissolution election that (Sir) Joseph Cook had called in wartime out of loyalty to the mother country. Labor won the election of 1914 and Hughes was appointed attorney-general under Prime Minister Andrew Fisher. When Fisher retired in October 1915, Hughes succeeded him, but in the following year the Australian Labor Party split as a result of Hughes pursuing conscription for overseas service. Hughes continued in office, nonetheless, as head of a Nationalist Government. ${ }^{3}$

During the course of World War I it became increasingly important for Australians to feel that they had a voice in the framing of the British Empire's policy in war and peace. Ever since 1915 the British Government had promised to consult the dominions on the terms of the peace that would end World War I. In December 1916, in fulfilment of this undertaking, Prime Minister Lloyd George decided to set up an Imperial War Cabinet, running concurrently with an Imperial War Conference, as the coordinating body for the British Empire's war effort and a source of advice on the terms of the peace. ${ }^{4}$ Much of the second session of the Imperial

3 L. F. Fitzhardinge, 'Hughes, William Morris (1862-1952)', in Australian Dictionary of Biography, vol. 9, ed. Bede Nairn and Geoffrey Serle (Carlton: Melbourne University Press, 1983), 392-400; L. F. Fitzhardinge, William Morris Hughes: A Political Biography (Sydney: Angus \& Robertson, 1964-1979); Carl Bridge, William Hughes: The Paris Peace Conferences of 1919-1923 and Their Aftermath (London: Haus Publishing, 2011); Peter Cochrane, Best We Forget: The War for White Australia, 1914-18 (Melbourne: Text Publishing Company, 2018).

4 Arthur Berriedale Keith, War Government of the British Dominions (Oxford: Clarendon Press, 1921), $27-47$. 
War Conference from June to July 1918 was devoted to discussion of the possible shape of the peace. Hughes actively participated in these discussions during a period when the outcome of the war was still in the balance. He had come to London accompanied by Garran, Cook and Latham, Percy Deane, his private secretary, and H.S. Gullet, a young journalist.

Cook had also been born in England, 2 years before Hughes. The son of a Staffordshire coalminer, he migrated to the colonies in the 1880 s, settling in Lithgow, New South Wales. After George Reid's retirement in 1908 he became leader of the Free Trade Party and, when Andrew Fisher's Labor Party was defeated in 1913, briefly became prime minister. After the wartime split in the Labor Party, he joined the new Nationalist Party and served under Hughes as minister for the navy. ${ }^{5}$ Garran was born in Sydney on 10 February 1867, youngest child of journalist and politician Andrew Garran. ${ }^{6}$ In 1901 he was appointed permanent secretary of the Commonwealth Attorney-General's Department, a post he held for the next 3 decades. Hughes drew heavily on Garran's abilities in World War I and a 'bond of mutual regard grew between the two men, who were superficially incongruous in every respect'? Hughes appointed Garran to the new statutory office of SolicitorGeneral in 1916 and delegated many wartime powers to him. As the Department of External Affairs had been abolished during the war, Garran accompanied Hughes to the Imperial Conference of 1918 as the prime minister's main public service adviser. Hughes also took with him a younger man, John Latham. Born in Melbourne in 1877 to a poor Methodist family, he had been a brilliant student, graduating from the University of Melbourne in 1896 and admitted to the Victorian Bar in 1904. In 1917, following allegations of union sabotage, he was appointed head of Naval Intelligence with the honorary rank of lieutenant-commander. His work in the navy on Australian security drew him to the attention of both Cook and Hughes who co-opted him to the delegation to the Imperial War Conference in $1918 .^{8}$

In June and July 1918, many people, like the then South African minister for defence Jan Smuts and Hughes himself, thought that the war would go into 1919 and perhaps even 1920. ${ }^{9}$ The Imperial War Conference was not in session in late August when a German collapse seemed possible and peace imminent. By that time, Hughes was the only dominion prime minister left in England, although Smuts,

5 F.K. Crowley, 'Cook, Sir Joseph (1860-1947)', in Australian Dictionary of Biography, vol 8, ed. Bede Nairn and Geoffrey Serle (Carlton: Melbourne University Press, 1981), 96-99.

6 R.S. Parker, 'Garran, Sir Robert Randolph (1867-1957)', in Australian Dictionary of Biography, vol. 8, ed. Bede Nairn and Geoffrey Serle (Carlton: Melbourne University Press, 1981), 622-25.

7 Parker, 'Garran, Sir Robert Randolph', 623.

8 Stuart Macintyre, 'Latham, Sir John Greig (1877-1964)', in Australian Dictionary of Biography, vol. 10, ed. Bede Nairn and Geoffey Serle (Carlton: Melbourne University Press, 1986), 2-6; David Lee, 'Sir John Latham and the League of Nations' in League of Nations: Histories, Legacies and Impact, ed. Joy Damousi and Patricia O'Brien (Carlton: Melbourne University Publishing, 2018), 83-99.

9 W.K. Hancock, Smuts, vol. 1, The Sanguine Years, 1870-1919 (Cambridge: Cambridge University Press, 1962), 493; cablegram from Hughes to Watt, 13 November 1918, National Archives of Australia (NAA), CP360/8, 2. 
prime minister of South Africa from September 1919, remained as a member of the Imperial War Cabinet. However, after the failure of their 'spring offensive' from March to July, the Central Powers recognised the hopelessness of their position. On 5 October they sent a message to United States President Woodrow Wilson seeking an armistice based on his 'Fourteen Points', ${ }^{10}$ a statement of principles for peace he had announced on 8 January 1918. Wilson had taken many democratic and progressive ideas, such as free trade, freedom of the seas, open agreements rather than secret treaties, democracy and self-determination, and translated them into foreign policy. ${ }^{11}$ Two of the points most disagreeable to Hughes were that there should be a new international organisation, a League of Nations, after the war and that the adjustment of all colonial claims should give weight to the interests of the populations concerned'. ${ }^{12}$ Hughes worried that such a body could potentially interfere with Australia's protectionist tariffs and its discriminatory 'White Australia' immigration policy. Wilson's idea of 'no annexations' put in jeopardy Hughes's hopes for Australia's permanent annexation of the German territories in the Pacific captured by Australia during the war: New Guinea and perhaps also Nauru whose phosphate was desired for the development of Australian agriculture. ${ }^{13}$ Hughes stayed on in London after the Imperial Conference to attend to a range of matters connected with Anglo-Australian relations, but the speed of the German collapse in late 1918 took him by surprise.

After returning from France where he met the French president, George Clemenceau, Hughes embarked on a speaking tour in northern England. With Hughes conveniently away from London, Lloyd George kept the dominion representatives at arm's length from discussions at Versailles held between 29 October and 4 November to discuss the armistice. The British decision-makers broadly accepted an armistice based in principle on Wilson's Fourteen Points without including a reservation on the retention of the captured German colonies by the dominions. An international conference was to convene in Paris the following year to frame the peace terms for the defeated Central Powers. ${ }^{14}$

10 Trygve Throntveit, 'The Fable of the Fourteen Points', Diplomatic History 35, no. 3 (June 2010): 445-81.

11 John N. Snell, 'Wilson on Germany and the Fourteen Points', Journal of Modern History 26, no. 4 (December 1954): 364-69; D. Fromkin, 'What is Wilsonianism?', World Policy Journal 11, no. 1 ( Spring 1994): 100-11; R.W. Tucker, 'The Triumph of Wilsonianism?', World Policy Journal 10, no. 4 (Winter 1993): 83-99; John Thompson, 'Wilsonianism: The Dynamics of a Conflicted Concept', International Affairs 86, no. 1 (January 2010): 27-47; L.E. Ambrosius, 'Woodrow Wilson and the Birth of a Nation: American Democracy and International Relations', Diplomacy \& Statecraft 18, no. 4 (December 2007): 689-718; Lloyd E. Ambrosius, Woodrow Wilson and the American Diplomatic Tradition: The Treaty Fight in Perspective (Cambridge: Cambridge University Press, 2007); Thomas J. Knock, To End All Wars: Woodrow Wilson and the Quest for a New World Order (New York: Oxford University Press, 1992); John Milton Cooper Jnr, Breaking the Heart of the World: Woodrow Wilson and the Fight for the League of Nations (Cambridge: Cambridge University Press, 2001).

12 'The Fourteen Points', Sunday Times (Sydney), 24 November 1918.

13 See W.M. Hughes, 'Australia and the Pacific Islands', 6 February 1919 and 'Memorandum Regarding the Pacific Islands', Latham Papers, MS 1009, Series 21, Box 61, Folder 19, National Library of Australia (NLA); and letter, Hughes to Lloyd George, 4 November 1918, Lloyd George Papers, House of Lords Records Office (LGP-HLRO).

14 Peter Spartalis, The Diplomatic Battles of Billy Hughes (Sydney: Hale \& Iremonger, 1983), 80-81. 
It was galling for Hughes that countries such as Greece and Portugal were represented at the armistice discussions while the dominions, which had played a much larger role in the allied war effort, were not. Irate, he protested the terms of the armistice in a meeting of the Imperial War Cabinet on 5 November. ${ }^{15}$ He professed himself unwilling to be 'bound to the chariot-wheels of the Fourteen Points' and neither would he be party to a League of Nations whose structure, functions and membership had not been defined. ${ }^{16}$ Hughes complained that the British Government had declared war without consulting the dominions and were now 'settling the Peace Terms equally without reference to Dominions being first consulted'. ${ }^{17}$ In a letter published in The Times, he reiterated his claim that he had not been informed of the discussions in Versailles until after they had been completed. ${ }^{18}$ The Imperial War Cabinet, he admitted, had previously discussed the question of peace terms but Wilson's Fourteen Points had never been agreed there. Moreover, ' $\mathrm{h}] \mathrm{ad}$ the conditions of peace as set out left no room for criticism, the mode of their settlement would still be quite incompatible with the relations which ought to exist between the self-governing Dominions and Britain'. ${ }^{19}$

Of the members of the Australian delegation to the 1918 Imperial War Conference, Garran also thought that severe damage could be done to the Empire by this 'altogether inexcusable and damnable decision'. ${ }^{20}$ Similarly, Latham was sympathetic to his protest about the lack of consultation with the British on the peace terms. He wrote to Philip Kerr, Lloyd George's private secretary and a fellow member of the Round Table Movement, warning that 'the people of the Dominions will be justified in believing that they cannot safely trust the leaders of Great Britain'. ${ }^{21}$ In Latham's notes for a subsequent address at the Round Table he included in the outline: '(1) Promise broken (2) Hands of separatists strengthened (3) Imperial War Cabinet and consultative system on which it is based has been proved to be deceptive'. 22

The support of the delegation for Hughes's criticism of the armistice stood in stark contrast with the attitude of the rest of the Australian Government. William Watt, the acting prime minister, was the most critical. A Deakinite Liberal and former

15 Imperial War Cabinet Minutes, 5 November 1918, Hughes Papers, MS 1538/111/4, NLA.

16 Imperial War Cabinet Minutes, 5 November 1918.

17 Imperial War Cabinet Minutes, no. 36A, 6 November 1919, CAB 23/44, United Kingdom National Archives (UKNA).

18 W.M. Hughes, Statement, The Times, 8 November 1918.

19 The Times, 9 November 1919. See also letter, Hughes to Lloyd George, 9 November 1918 and letter, Lloyd George to Hughes, 11 November 1918, LGP-HLRO.

20 Garran Diary, 9 November 1918, Garran Papers, MS 2001/7, NLA. See also Leonie Foster, High Hopes: The Men and Motives of the Australian Round Table (Carlton: Melbourne University Press, 1986), 84.

21 Letter, Latham to Kerr, 9 November 1918, Latham Papers, MS 1009/19/25, NLA.

22 Latham to Kerr, 9 November 1918; 'Rough Notes for Address to the Round Table', 21 November 1918. For Latham's connections with Kerr and other British members of the Round Table Movement, see John E. Kendle, The Round Table Movement and Imperial Union (Toronto: University of Toronto Press, 1975), 222. 
premier of Victoria who held orthodox views about the place of a dominion in world affairs, he told the governor-general Ronald Munro-Ferguson that he greatly regretted Hughes's public criticism of Lloyd George. ${ }^{23}$ At the end of 1918, Watt, anxious for Hughes to return to Australia to give ballast to an unstable government, thought that the dominions should not be represented at the Paris Peace Conference and that the Empire should gain control over the German colonies south of the equator before handing them to Australian administrative control. ${ }^{24}$ MunroFerguson also thought that it was highly improper and impudent for Hughes to suggest that Australia should have had a role in the armistice discussions and that 'Hughes has done the most mischievous thing possible, and exposed his flank to his enemies in a deliberate endeavour to stir up bad blood between Eng[land] and Aust[ralia]'. ${ }^{25}$

One of the Hughes's main concerns was that Japan would be invited to the 1919 Peace Conference in Paris and not Australia. At a meeting of the Imperial War Cabinet on 6 November he pointedly asked: 'Why should Japan be included and Australia excluded from the Peace Conference? What sacrifices had Japan made which were in any way comparable with those of Australia?'26 In this his cabinet colleagues felt that Hughes had gone too far. Watt cautioned him:

We think that a claim either express or inferential of the right of Dominions to representation on Versailles Council cannot be sustained. This view applies of course to Peace Conference if you are thinking of it in the same way. If our conception of your attitude on this matter is correct, your colleagues ask you to reconsider this phase very carefully. ${ }^{27}$

Weeks before Hughes made his protest on the terms of the armistice, Lloyd George had sounded out the measured and congenial prime minister of Canada, Sir Robert Borden, on whether he might participate in discussions of the policies the British should take to the Paris Peace Conference. In his reply on 29 October 1918, Borden first explicitly raised the issue of Canadian representation in Paris, pointing out that the 'press and people of this country take it for granted that Canada will be represented at the Peace Conference'. ${ }^{28}$ As Hughes's biographer L.F. Fitzhardinge has pointed out, Lloyd George at that time was almost certainly not in favour of representation of dominions in Paris, and Borden had made no suggestion as to its form. ${ }^{29}$ What both probably had in mind was a single British Empire delegation

\footnotetext{
23 Lord Novar, Diary Entry, 9 November 1918.

24 Lord Novar, Diary Entry, 3 December 1918.

25 Lord Novar, Diary Entry, 20 November 1918.

26 Imperial War Cabinet Minutes, no. 36A, 6 November 1918, CAB 23/44, UKNA.

27 Cablegram, Watt to Hughes, 14 November 1918, NAA CP 360/8, 2.

28 Quoted in R. M. Dawson (ed.), The Development of Dominion Status 1900-1936 (London: Oxford University Press, 1937), 178-79.

29 L. F. Fitzhardinge, 'Hughes, Borden, and Dominion Representation at the Paris Peace Conference', The Canadian Historical Review 49, no. 2 (1968): 162-63.
} 
that included Borden but still acted as a unit. When Borden reached England on 17 November, he discussed arrangements for the Peace Conference with Lloyd George and Andrew Bonar Law, chancellor of the exchequer. They suggested a delegation to the Paris Peace Conference consisting of Lloyd George, Bonar Law, Arthur Balfour, secretary of state for foreign affairs, and George Barnes, minister without portfolio, with Borden included as a special representative of the dominions. Borden demurred at having 'any special status to represent the Dominions', but he later consulted Smuts who agreed that Borden should go to Paris not as the special representative of the dominions but as an 'Empire Delegate'. ${ }^{30}$

As Lloyd George considered arrangements for the conference, he was shaken by Hughes's public criticisms of Britain's lack of consultation with the dominions on the peace. In the Imperial War Cabinet on 20 November 1918 he sought to involve them in shaping British policy, although not yet conceding to them the right to separate representation at the conference. To mollify them, he agreed that an Allied conference should precede the Peace Conference and that India and the self-governing dominions should have the fullest opportunity to express their opinions on 'questions which may closely concern them'. ${ }^{31}$ Meanwhile, Hughes let Borden know that he would oppose the representation of any other dominion at the conference unless he himself was also appointed. To try to resolve the impasse between Hughes and Borden, Smuts suggested that the fifth place in the British delegation should be filled periodically and in rotation from a panel of dominion representatives. ${ }^{32}$ By this time, Borden's cabinet colleagues in Ottawa was pushing him towards being formally a part of a British delegation in Paris. ${ }^{33}$

The reverse was the case in Australia. Critics in the House of Representatives attacked Hughes's apparent push for Australian representation as unorthodox and inappropriate for a dominion of the British Empire. ${ }^{34}$ Hughes though, supported by the delegation, was not deterred from pressing Australia's claims. It was particularly important that Hughes had the support of Cook, a former prime minister and second in seniority in the Cabinet, in making this claim. By early December the British Government conceded that the representatives of the dominions could attend as additional members of the British delegation when questions directly affecting them were being considered. On 30 December 1918 an unappeased Hughes again made

30 Fitzhardinge, 'Hughes, Borden, and Dominion Representation', 163; Hancock, Smuts, vol. 1, 496-97.

31 Fitzhardinge, 'Hughes, Borden and Dominion Representation', 164.

32 Letter, Smuts to Lloyd George, 3 December 1918, LGP-HLRO, Australian Joint Copying Project (AJCP), Reel 2 - M1125-947 Series F, NLA.

33 Cablegram from White to Borden, 4 December 1918, in Documents on Canadian External Relations, vol. 2, The Paris Peace Conference of 1919, ed. R. A. MacKay (Ottawa: Department of External Affairs, 1969), 7.

34 Commonwealth Parliamentary Debates, XCIV (1920), 5817. 
a blistering attack in the Imperial War Cabinet on Wilson's Fourteen Points and gained some support for his remarks from the colonial secretary, Walter Long, and in Melbourne from Munro-Ferguson. ${ }^{35}$

At length, on 31 December, the Imperial War Cabinet discussed the idea of the Great Powers (Great Britain, France, Italy, Japan and the United States) being represented by 5 plenipotentiary delegates. But Hughes strongly criticised a state of affairs in which each dominion would be accorded lesser representation at the conference than countries such as Sweden. He suggested that when the conference discussed this question, the dominions should be entitled to representation equal to that accorded to neutrals, given that Australia had put and kept more men in the field than Belgium. ${ }^{36}$ Although Borden would have accepted a position of himself being the Empire representative on the British delegation, this option had been stymied by Hughes's opposition. Borden therefore reverted to Smuts's compromise in which the dominion prime ministers should be part of the British delegation, with one or more of them sitting periodically on the delegation representing the British Empire at the conference. Lloyd George warned, however, that a British delegation swelled to comprise 5 delegates from Britain and 3 each from the self-governing dominions would be unwieldy and out of proportion with other countries' delegations.

Out of all this came the ingenious compromise in which representatives of the dominions in Paris would have a dual position as delegates in their own right as well as alternate members of the British delegation. ${ }^{37}$ This decision had far-reaching implications, among them separate dominion signatures on the Peace Treaty and full dominion membership of the League of Nations as quasi-independent states. This solution was fully realised when Lloyd George made the case in January 1919 for dominion representation at the conference to his French, Italian and American colleagues. Wilson and his Secretary of State, Robert Lansing, at first opposed the principle of separate dominion representation. However, Lloyd George made such a strong case that the other countries relented. ${ }^{38}$ On 13 January he succeeded in having approved 2 representatives each for Canada, Australia and South Africa, and one each for New Zealand and British India at the conference. This meant that the Australian delegation included Hughes and Cook as plenipotentiaries of Australia and a supporting staff of their Australian advisers including Garran as adviser on legal questions.

35 Fitzhardinge, 'Hughes, Borden and Dominion Representation', 166.

36 Extract from Minutes of Forty-Eighth Meeting of Imperial War Cabinet, 31 December 1918, in Documents on Canadian External Relations, vol. 2, 18.

37 Fitzhardinge, 'Hughes, Borden and Dominion Representation', 167-68.

38 Minutes of First Meeting of British Empire Delegation, 13 January 1919, in Documents on Canadian External Relations, vol. 2, 26. 
Winning of the right to separate dominion representation was of great significance for Australia's political and constitutional history and its path to consolidating its status as an independent sovereign state. ${ }^{39}$ Many historians ascribe particular importance to Borden's role in achieving this outcome for his dominion as well as Australia. ${ }^{40}$ Hughes, however, was perhaps even more important than either Borden or Smuts, first by blocking the idea of Borden as an Empire delegate and then by stymying Smuts's idea of a single British Empire delegation working with a panel of dominion representatives. Hughes was not a systematic thinker concerned with constitutional principles such as dominion autonomy (of the kind supported by Borden and Smuts) or with separatism (which he and his country abhorred). He was simply a political pragmatist who regarded it as intolerable that Japan could be seated as a Great Power at the conference while Australia was relegated to a subordinate role. Moreover, he was driven by the compelling strategic concern of gaining Australian control over the German colonies south of the equator. Borden, by contrast, had no desire for Canadian control over German colonies.

Ironically, Hughes probably contributed more than Smuts and Borden to the recognition of separate dominion representation at the Paris Peace Conference. In obtaining this outcome, Hughes was not supported at all by his cabinet colleagues in Melbourne, even by his fellow ex-Laborite and minister for defence, George Pearce. ${ }^{41} \mathrm{He}$ was, however, supported by his delegation to the Imperial Conference, especially his loyal private secretary, Percy Deane, by Garran and Latham, who pushed his minister, Joseph Cook, to let him play a role in Paris. All these men would play a part in the Australian delegation to the conference in 1919. The Victorian lawyer, Frederic Eggleston, also joined the Australian delegation in late 1918. When Hughes and his party came to England in 1918 to attend the Imperial War Conference, Eggleston, who was already in London, had the advantage of knowing Garran and Latham, all of them being members of the Round Table Movement. In December 1918 Garran advised Hughes to ask for Eggleston to be invited to support the Australian delegation at the Peace Conference. ${ }^{42}$

39 See W.J. Hudson and M.P. Sharp, Australian Independence: Colony to Reluctant Kingdom (Carlton: Melbourne University Press, 1988); and Arthur Berriedale Keith, The Dominions as Sovereign States (London: Macmillan, 1938). 40 See, for example, Brian Douglas Tennyson, Canada's Great War, 1914-1918 (Lanham: Rowman and Littlefield, 2014), 171.

41 John Connor, Anzac and Empire: George Foster Pearce and the Foundations of Australian Defence (Port Melbourne: Cambridge University Press, 2011).

42 Warren Osmond, 'Eggleston, Sir Frederic William (1875-1954)', Australian Dictionary of Biography, vol. 8, ed. Bede Nairn and Geoffrey Serle (Carlton: Melbourne University Press, 1981), 421-24; Warren Osmond, Frederic Eggleston: An Intellectual in Australian Politics (Sydney: Allen \& Unwin, 1985). 


\section{Pacific mandates}

One of the key objectives of the Australian delegation to the conference was to secure control over the former German colonies in the South Pacific and, if possible, to prevent the Japanese gaining influence over those in the North Pacific. The future status of Pacific territories was one of the subjects discussed at the Imperial Conference of 1917 that Hughes was unable to attend. In 1917, although Hughes had a comfortable majority in the House of Representatives, he lacked one in the Senate. Consequently, he was unable to extend the life of the Australian Parliament until October 1918 and had to have the parliament dissolved in March 1917, go to the hustings and then face a national election on 5 May. By that time, Hughes had lost confidence in his former chief, Andrew Fisher, the current High Commissioner in London, and was unwilling to allow him to represent Australia at the Imperial War Conference. The result was that Australia was unrepresented at a particularly important meeting. One of the most significant developments at the 1917 conference was a successful effort by Borden and Smuts to head off the idea of a federated British Empire. They did so by sponsoring a successful resolution, Resolution IX, that the dominions should be recognised as 'autonomous nations of an Imperial Commonwealth' having the right to an 'adequate voice in foreign policy and in foreign relations' ${ }^{43}$

Even before the 1917 conference began, the British Government had made an agreement to secure increased naval assistance from its ally, Japan. In return, the British agreed to support Japan's campaign for its permanent occupation of former German island possessions in the North Pacific. The Colonial Office secured from Hughes's new Nationalist Government a grudging acquiescence in the arrangement. Hughes was never happy with the deal and hoped that he could cooperate with the United States to oppose the longer-term occupation of the islands by the Japanese. ${ }^{44}$

By 1918 the colonial secretary, Walter Long, had become aware of a potential difference of opinion between the peace aims of the British and the Americans over the right of populations to determine their own futures and the application of that principle to the people of German New Guinea. ${ }^{45}$ Long was correctly anticipating that the United States would insist on territories such as German New Guinea not being annexed by Australia as one of the spoils of war, but rather being administered as a mandate of the new League of Nations. He urged Australians to obtain expressions of opinion on the wishes of the peoples of German New Guinea to 'live under British rule. ${ }^{46}$ Hughes referred Long's cablegram to Joseph Cook, the minister for the navy, who in turn passed it to Latham in his role with Naval Intelligence.

43 Foster, High Hopes, 84.

44 See Hughes's letter to Lloyd George, 4 November 1918, LGP-HLRO.

45 Telegram, Long to Governor-General quoted in Spartalis, Diplomatic Battles, 54.

46 Telegram, Long to Governor-General. 
Cook and Latham thereafter developed the political and strategic arguments for Australian annexation, or the loosest possible form of mandate, over the German colonies south of the equator.

Latham made a detailed study of the pronouncements on the shape of peace by Lloyd George, Wilson and Pope Benedict XV. ${ }^{47}$ In light of this study, he recommended that Australia should adopt a policy to German New Guinea that had at its heart the welfare of the native peoples. To that end, he pointed to the usefulness of Australia promoting its economic and commercial interests in the colony during wartime occupation. Australia's objective, he argued, should be to bolster its case for longterm control over the colony by pointing out to other countries both the strength of Australian interests in the colony and the attenuation of German interests. ${ }^{48} \mathrm{Cook}$ passed Latham's memorandum to Hughes who asked that Latham be included in the Australian delegation to the Imperial War Conference of 1918. As part of the delegation there, Latham produced a 'Memorandum on the Pacific' in July 1918. ${ }^{49}$ In this he mounted a strong argument for Australia's retention of the German colonies south of the equator based on its defence and strategic requirements, the development of its resources and the protection of British trade in the Pacific. ${ }^{50}$ The paper also pointed to the benefits of an alliance between Britain and the United States to secure Anglo-American supremacy in the Pacific. ${ }^{51}$ Hughes was impressed by Latham's paper and used it as the basis of his arguments at the Imperial War Conference and Paris Peace Conference in the following year.

Having missed out on the Imperial War Conference of 1917, Hughes was determined to make a mark when it resumed in 1918. On 23 January 1919, Lloyd George took the case of the British Empire on the German colonies to the Paris Peace Conference. He argued for South-West Africa and the former German colonies in the Pacific to be allowed to be annexed by the dominions and exempted from Wilson's proposed mandatory system (the system in which former enemy territories would be administered on behalf of the League of Nations and according to principles agreed by the League). ${ }^{52}$ Hughes followed by making a forceful claim for Australian annexation on the grounds of Australian security, the welfare of the native inhabitants and the costs placed on a small country such as Australia on fighting World War I. Garran was unhappy with the session, describing it as 'very unsatisfactory'. ${ }^{53}$ His doubts about the impact of the British/Australian case intensified when Wilson defended the principle of the mandatory system under

\footnotetext{
47 J.G. Latham, 'Former German Colonies in the Pacific', 16 January 1918, NAA MP1049/1, 1919/0118.

48 Latham, 'Former German Colonies in the Pacific'.

49 J.G. Latham, 'Memorandum on the Pacific', 23 July 1918; also J. G. Latham, 'The Surrender of German Forces in the Pacific', 11 July 1918 and 'Report on Defence Policy for Australia', NAA B6121, 184J.

50 Latham, 'Memorandum on the Pacific'.

51 Latham, 'Memorandum on the Pacific'.

52 British Empire Delegation Minutes, no. 3, 23 January 1919, Garran Papers, NAA CP351/1, 2/12, and CAB 29/28, UKNA.

53 Garran Diary, 24 January 1919, Garran Papers, MS 2001/13, NLA.
} 
the League of Nations with no exceptions. In Wilson's mind a new world order had been born and arguments such as those of Hughes for annexation simply reflected a lack of faith in the League of Nations. ${ }^{54}$

Hughes's case for New Guinea was built upon work on which Cook and Latham in particular had been labouring for some time. ${ }^{55}$ They had helped develop a historical case stretching back to the 1880s when Queensland had pushed Britain to colonise New Guinea. Britain had resisted and then been outmanoeuvred by Germany. The vigour of Australia's claim, however, raised anxiety among leading figures in Lloyd George's government who feared that Wilson might walk out of the Paris Peace Conference. Borden confided to a cabinet colleague: 'You know that I have taken a strong ground against large annexations of territory to the British Empire. I rather fear that we are heading to disaster by that route. ${ }^{56}$ Lord Robert Cecil, a leading Conservative and enthusiast for the League of Nations, urged Balfour to lead a retreat on Lloyd George's fight for the dominions and supported the mandatory principle in a meeting of the British delegation. Edwin Montagu, another member of the British delegation, warned Lloyd George:

The peace of the world and the success of future arrangements are all jeopardized by the attitude of Australia. Anyone who heard Lord Robert Cecil this afternoon and anyone who heard Mr. Hughes's answer can realize that Australia has no case except this, that she is there and intends to remain there ... If we allow an exception for the mandatory rule for Australia we open the door to all sorts of exception by the French and the Japanese.. $.7^{57}$

Montagu wondered whether Australia could be persuaded to accept the mandatory principle if it was allowed to apply its own immigration laws to the mandate. ${ }^{58}$

Following a meeting of the British delegation on 28 January, several of its members worked assiduously to find a way out of an impasse that threatened to wreck the conference. Smuts and Cecil discerned 2 kinds of mandates: A class mandates that applied mainly to former Ottoman territories and gave them a high degree of autonomy; and $B$ class mandates that applied to peoples from less developed territories that were given a lesser degree of autonomy. ${ }^{59}$ A further class of mandate was then devised to satisfy Australia, New Zealand and South Africa. If they were

54 Quoted in Spartalis, Diplomatic Battles, 127.

55 J.G. Latham, 'Mandatory System and the German Pacific Islands', 21 January 1919, Sir Joseph Cook Papers, MS 762, Folder 1, NLA.

56 Letter, Borden to President of Privy Council, 25 January 1919, in Documents on Canadian External Relations, vol. 2, 41 .

57 Letter, Montagu to Lloyd George, 28 January 1919, LGP-HLRO, AJCP NLA.

58 Letter, Montagu to Lloyd George, 28 January 1919.

59 Memorandum by Lord Milner, 'Mandates under Clause 19 of the Draft "Covenant" of the League of Nations', 8 March 1919, Latham Papers, MS 1009, Series 21, Box 60, NLA. On Smuts's role see I. C. Smith, 'J.C. Smuts' Role in the Establishment of the League of Nations and the Mandate for S.W.A', South African Historical Journal 5 , no. 1 (November 1973): 94-107. 
not able to achieve outright annexation, $\mathrm{C}$ class mandates would give the mandatory powers much more extensive authority than those responsible for $\mathrm{A}$ and $\mathrm{B}$ class mandates. The Australian historian Duncan Hall ascribed authorship of the C class mandates to Smuts and Kerr. ${ }^{60}$ Garran in his memoir, Prosper the Commonwealth, recalled that its authors were Sir Cecil Hurst, the British legal adviser, and Latham, who would later rise to be Chief Justice of the High Court of Australia. ${ }^{61}$ Latham himself later recalled that he had drafted the clause for the $\mathrm{C}$ class mandate and shown it to the secretary of the Imperial War Cabinet and of the British delegation in Paris, Sir Maurice Hankey, and that Hankey took it to Lloyd George for approval. Whoever were its authors, and Latham has a large claim to it, the terms of the proposed clause for a $\mathrm{C}$ class mandate were:

There are territories such as South West Africa and the Pacific Islands which, owing to the sparseness of their population or their small size, or their remoteness from the centres of civilisation, or their geographical contiguity to the mandatory State, and other circumstances, can best be administered under the laws of the mandatory State as integral portions thereof, subject to the safeguards abovementioned in the interests of the indigenous population. ${ }^{62}$

Hughes still preferred outright Australian annexation of New Guinea but recognised that Lloyd George was now unprepared to go further than a $\mathrm{C}$ class mandate. This did not stop Hughes from trying to further his cause by placing articles in the press. One such article in The Times on 29 January made a public appeal for Britain to support the case of the dominions. Another in the Paris Boulevard Edition of the Daily Mail contended that the Australian delegation believed that Wilson's stand against dominion annexation was due mainly to his fear that if Japan was allowed to annex the German islands north of the equator, there would be an outcry in America and particularly in the Congress. ${ }^{63}$ Eggleston rightly believed that Hughes had orchestrated the leaks to the newspaper. ${ }^{64}$ Latham did not say anything at the time, but he supported the clause for a $\mathrm{C}$ class mandate that he had played a part in devising. In 1920, in a defence of the new League of Nations and in support of Eggleston, he argued that for Australia to have insisted on outright annexation would have been a disaster as it would have allowed Japan to fortify and build naval bases right up to the equator. ${ }^{65}$

60 Duncan Hall, The Commonwealth: A History of the British Commonwealth of Nations (London: Van Nostrand Reinhold, 1971), 916.

61 Robert Randolph Garran, Prosper the Commonwealth (Sydney: Angus and Robertson, 1958), 264-65.

62 'Draft Resolutions in Reference to Mandatories' as presented by Lloyd George to the British Empire Delegation, minutes no. 6, 29 January 1919, Garran Papers, NAA CP351/1, 2/12.

63 Daily Mail (Boulevard Edition), 30 January 1919; see also Sydney Sun, 31 January 1919.

64 Eggleston Diary, 30 January 1919, Eggleston Papers, MS 423/6/82-5, NLA.

65 J.G. Latham, The Significance of the Peace Conference from the Australian Point of View (Melbourne: Melville and Mullen, 1920), 12. 
Wilson, stung by the Australian leaks to the newspapers, accepted the compromise of the $\mathrm{C}$ class mandate, but argued that the mandatory states could not actually be selected before the League of Nations was actually approved after the signing of the Peace Treaty. Forced grudgingly to accept a C class mandate, Hughes told Wilson that Australia would not take part in any agreement at all unless the mandatory states were immediately confirmed. Out of this came a compromise brokered by the genius of Lloyd George. Referring to (Hughes's) press leaks that had conveyed the impression of disunity between the British and the Americans, he suggested a communiqué that would announce a satisfactory provisional agreement. This agreement included recognition of the mandatory principle, and that the League would supervise mandated territories. There would not be any immediate distribution of the 'spoils of war', but the acceptance of the $\mathrm{C}$ class mandate clause meant that dominions contiguous with the mandatory states would in practice have to be accepted by the League of Nations as mandatories. Hughes admitted as much when he summarised the position for Watt:

Our position is in some respects better under the mandatory system, if we get it in the above form, than if we were in outright control because Japan under mandatory system cannot and must not fortify Marshall and Carolines or use them for submarine or naval base. ${ }^{66}$

\section{The League of Nations and racial equality}

Hughes was always dubious about Woodrow Wilson's concept of a League of Nations. He preferred to rely for Australian security on the might of the British Empire bolstered perhaps by an Anglo-American alliance. Garran agreed with Hughes inasmuch as Wilson, an 'extraordinary able but a dangerous man', had failed to think through his concept of the League of Nations. ${ }^{67}$ It was left to other statesmen such as Smuts and Cecil to realise fully Wilson's concept. Garran, however, was less predisposed against a British-designed League of Nations than Hughes, and his colleague Latham later became one of the staunchest supporters of the new organisation in Australia. But even though Hughes was sceptical about Wilson's concept of a League of Nations, he was protective of Australia's position in the new world organisation. If there was to be a League of Nations, Hughes wanted to ensure that Australia, though still a British dominion, could be a member of it with the fullest opportunities. In a meeting of the British delegation on 3 January 1919, for example, Hughes criticised the lack of explicit language on the right to dominion representation in the League. He referred to Australia's usual acquiescence in the practice of the British Foreign Minister representing the whole

66 Cablegram, Hughes to Watt, 31 January 1919, NAA CP360/8, 3.

67 Spartalis, Diplomatic Battles, 115. 
British Commonwealth in diplomatic negotiations with foreign powers. ${ }^{68}$ But when it came to the new institution, this created a position in which Australians were asked expressly to nominate the British Foreign Secretary as their representative in addressing foreign powers. ${ }^{69}$ In such a situation, Hughes insisted on departing from usual practice and securing Australian representation in the League without mediation by the British.

When Japan participated as a Great Power in the Paris Peace Conference, it had the specific objectives of gaining control over Germany's possessions in the North Pacific and China. Beyond that, the Imperial Japanese Government was so concerned about the degree of racial discrimination prevailing in international relations that it instructed its delegation to press for an international commitment to abolish racial discrimination. ${ }^{70}$ On 13 February, Baron Makino, head of the Japanese delegation, presented its proposal for insertion into the Covenant of the League of Nations to the league commission of the Paris Peace Conference:

The equality of nations being a basic principle of the League of Nations, the [High Contracting Parties] agree to accord, as soon as possible, to all alien nationals of States members of the League equal and just treatment in every respect, making no distinction, either in law or in fact, on account of their race and nationality.

This was exactly the sort of proposal that Hughes feared might be associated with the new world organisation.

Japan, encountering resistance from the US and British delegations, issued a new claim on 4 March. The Japanese delegation indicated that it would be content with a statement of principle on racial discrimination and would not seek immediate changes in domestic legislation that conflicted with that principle. The implication of the concession, however, was equally alarming for Hughes. It presaged that at some stage the Japanese would eventually seek changes in racially discriminatory legislation of other states, such as Australia's White Australia policy. In February the Japanese sought to devote much diplomatic effort into persuading those most resistant to their proposal, namely the British 'colonies'. During that month the Japanese delegation put its case to both Hughes and to Garran but received a noncommittal reply from both. To resolve the impasse, Cecil convinced Borden to host on 25 February a meeting at his flat that included the Japanese, the dominion leaders and himself as an intermediary. At the meeting Hughes pleaded not drafting difficulties but the fact that 95 out of every 100 Australians would unite in resisting the

68 See Keith, Dominions as Sovereign States, 3-14.

69 Minutes of Second Meeting of Committee on Position of Dominions and India in the League of Nations, 3 January 1919, in Documents on Canadian External Relations, vol. 2, 22.

70 See Naoko Shimuzu, Japan, Race and Equality: The Racial Equality Proposal of 1919 (London: Taylor \& Francis, 2002). 
principle that underlay the proposal. ${ }^{71}$ Privately, Hughes commented: 'The Japanese wish to insert the above amendment in the Preamble. It may be all right. But sooner than agree to it I would walk into the Seine-or the Folies Bergère with my clothes off.' ${ }^{72}$ Over the next few weeks Hughes (supported by Garran) continued to resist the Japanese racial equality clause even at the risk of Japan walking out of the League.

Cecil, in frustration, complained to Borden in April:

I cannot help regretting the completely non possumus attitude assumed by Hughes. It would be refreshing if that statesman could for once make a constructive suggestion, instead of devoting his great abilities exclusively to destroying every proposal made by others ... Unless something is done I am afraid that the Japanese will make a public protest against our attitude on the question and attract a very great deal of European sympathy from those nations who have no Asiatic question to deal with and this will be all the more regrettable since they are our Allies. Further, it is possible that they may refuse to join the League of Nations - a result which will materially increase the insecurity of Australia, apart from its disadvantages. ${ }^{73}$

The upshot was that continued Australian resistance combined with Woodrow Wilson's reluctance to allow interference with America's own racially discriminatory immigration laws to defeat the Japanese proposal. Wilson, however, was able to appease the Japanese by supporting their claims not only to Germany's Pacific territories in the North Pacific but to the Shandong Peninsula in China as well. ${ }^{74}$ On the basis of this compromise, Japan remained in the League without a racial equality clause and Hughes and Cook were able to sign the Peace Treaty for Australia on 28 June 1919.

\section{The delegation in Paris and Australian independence}

While the Australian delegation in Paris did not obtain what it wanted in reparations from the defeated Central Powers, it succeeded in getting mandates over German New Guinea and later Nauru, and was able to oppose a clause on racial equality in the League Covenant and secure the right of the dominions to be represented in the League and even on the League Council. ${ }^{75}$ Hughes and the other dominion leaders had been insistent that all the treaties and conventions resulting from the Peace

\footnotetext{
71 Spartalis, Diplomatic Battles, 175.

72 Spartalis, Diplomatic Battles, 175.

73 Letter, Cecil to Borden, 2 April 1919, in Documents on Canadian External Relations, vol. 2, 104-5.

74 Kristofer Allerfeldt, 'Wilsonian Pragmatism? Woodrow Wilson, Japanese Immigration and the Paris Peace Conference', Diplomatic History 15, no. 3 (September 2004): 545-72. W. H. Donald, an ex-patriot Australian in China, wrote a bitter letter of complaint to Hughes about this on 1 September 1919, Hughes Papers, MS 1538, Series 16, Box 103, NLA.

75 For the reparations issue see Spartalis, Diplomatic Battles, chapter 7.
} 
Conference should be drafted so as to enable the dominions to become parties and signatories to them. Borden and Smuts, in particular, were keen to emphasise that separate dominion signatures on the peace treaties were consonant with the idea of the Crown acting as the supreme executive in the United Kingdom and the dominions but on the advice of different ministries with different constitutional units. ${ }^{76}$ Hughes, moreover, later sided with Smuts against Borden in agreeing that the dominion signatures on the Peace Treaty entitled the dominions to make laws for their mandates without needing to be empowered to do so by British legislation. ${ }^{77}$

This was consistent with the resolution that Borden and Smuts (but not Hughes) had championed in the Imperial War Conference of 1917: Resolution IX claiming that the organisation of the Empire would be based on autonomy and equality of nationhood. It was potentially inconsistent with the Australian idea championed by Liberals such as William Watt that continued throughout the interwar period. This was that the British Empire should speak with one voice in foreign policy. ${ }^{78}$ Addressing the Commonwealth Parliament after the conference, Hughes argued that 'separate representation' at Paris meant that Australia had become a nation and entered into a family of nations on the 'footing of equality'. ${ }^{79}$ But other members of the delegation like Eggleston worried that Australia might find itself in a worse situation after the conference than before as it meant that Australia would henceforth be deprived of the 'authority' of England in its external relations. ${ }^{80}$ Hughes eventually felt the force of these arguments himself when he attempted to walk back from the full implications of Australia's greater independence at the Imperial Conference in 1921. ${ }^{81}$ There, supported by Joseph Cook as high commissioner in London, he torpedoed a proposal from the South African prime minister, Jan Smuts, to clarify the constitutional status of the dominions. ${ }^{82}$ Hughes found it advantageous in dealing with countries such as Japan to retain ambiguity on whether Australia was speaking as an autonomous dominion or as part of the British Empire.

While Hughes remained lukewarm to the League of Nations in the interwar period, he did insist that Australia should have full voting rights there rather than there being a bloc British Empire vote. ${ }^{83}$ Latham became a staunch advocate of the new organisation and a founding member of the League of Nations Union in

\footnotetext{
76 Memorandum by Borden on Dominions as Parties and Signatories to Peace Treaties, 12 March 1919, in Documents on Canadian External Relations, vol. 2, 72.

77 Cablegram from Hughes to Secretary of State for the Colonies, 11 February 1920, NAA CP4/11.

78 See David Lee, Australia and the British Empire between the Wars (London: Menzies Centre for Australian Studies, 2004).

79 Spartalis, Diplomatic Battles, 120.

80 Osmond, Frederic Eggleston, 96.

81 See also James Cotton, 'William Morris Hughes: Empire and Nationalism: The Legacy of the First World War', Australian Historical Studies 46, no. 1 (2015): 11-18.

82 W.K. Hancock, Smuts, vol. 2, The Fields of Force, 1919-1950 (Cambridge: Cambridge University Press, 1968), 48-9.

83 Cablegram from Hughes to Secretary of State for the Colonies, 14 November 1919, NAA A981, UNI53.
} 
Victoria. Indeed, he presaged in 1920 that Australian membership of the League would necessitate a great number of Australians being represented abroad. ${ }^{84}$ Both he and Stanley Bruce, a fellow Victorian, were advocates for Australian activism in the League. The Australian delegation's diplomacy in 1919 had helped this become possible. Australia became an independent member of the League, holder of League of Nation mandates, and a member of the League Council, all of which contributed to building Australia's personality as an international actor in its own right. Latham's personal antipathy to Hughes saw him caucus with the newly formed Country Party when he was elected to the House of Representatives in 1922. After the Country Party toppled Hughes as prime minister, Latham joined Bruce's NationalistCountry Party administration as attorney-general in 1925. In that capacity, he accompanied Bruce to the Imperial Conference of 1926 that defined the United Kingdom and dominions as 'autonomous communities' that were 'equal in status'. ${ }^{85}$

In 1930 when Latham was leader of the Opposition, Garran, still Australia's Solicitor-General, helped Labor Prime Minister James Scullin to negotiate with the United Kingdom the passage through the British Parliament of the Statute of Westminster. This legislation established the legislative independence of the selfgoverning dominions. After Latham became minister for external affairs and attorneygeneral, he recommended to Cabinet in 1933 that the Australian Parliament should adopt the Statute of Westminster and thus put the finishing touches on Australia's status as an independent state. ${ }^{86}$ This would not happen until 1942 under the Curtin administration. In the meantime, Latham and Eggleston, who had served as solicitor-general of Victoria from 1924 to 1927, remained keenly interested in Australia's external relations, leading to the former becoming Australia's first minister to Japan in 1940 and the latter Australia's first minister to China in 1941.

The Australian delegation to the Paris Peace Conference of 1919 was a remarkable one. It consisted of members of the Round Table movement aimed at closer union between Britain and the dominions (Garran, Latham and Eggleston), W.M. Hughes, an advocate of Australian self-government within a powerful Empire, and Joseph Cook, a free-trade Liberal. All of them were committed before the war to Australia's integration in a tight-knit British Empire, but they combined in 1919 to put Australia on a path that would see Australia becoming an independent nation-state by the time of World War II. Moreover, they achieved the successes they did in opposition to the views of the majority of Hughes's Cabinet and often against the wishes of the British Government.

84 Latham, Significance of the Peace Conference, 15.

85 David Lee, Stanley Melbourne Bruce: Australian Internationalist (London and New York: Continuum, 2010), 67-69.

86 David Lee, 'States Rights and Australia’s Adoption of the Statute of Westminster, 1931-1942', History Australia 13, no. 2 (April 2016): 258-74. 
This text is taken from Australian Journal of Biography and History: No. 4, 2020, published 2020 by ANU Press, The Australian National University, Canberra, Australia.

doi.org/10.22459/AJBH.04.2020.07 